\title{
Management of lettuce rot caused by Fusarium oxysporum f. sp. lactucae in hydroponically grown crop using microbial consortia
}

\author{
PARVEEN KHAN*, LOHIT CHANDRA BORA and PRADIP KUMAR BORAH \\ Department of Plant Pathology, Assam Agricultural University, Jorhat 785 013, Assam, India
}

Received: 24 March 2017/ Accepted: 30 May 2017/ Published online: 31 May 2017

(c) Indian Phytopathological Society 2017

\begin{abstract}
Hydroponics or growing plants on mineral nutrient solutions without soil has many advantages, as the system has higher water and fertilizer use efficiency, and crop encounters very low pest and disease incidence which inevitably check the requirement of plant protection chemicals. However, recently few of the diseases caused by commonly observed pathogens in conventional soil based system have also been detected in hydroponic culture, bringing a serious risk to hydroponic crop production. The present investigation was made to assess the effectiveness of bio-intensive management of Fusarium rot of lettuce incited by Fusarium oxysporum f. sp. lactucae (FoL) under hydroponic culture tank system in Assam during 2014-2016. Three rhizosphere inhabiting microbial agents, viz., Trichoderma harzianum, Bacillus thuringiensis and Pseudomonas fluorescens were tested singly as well as in consortia against the pathogen. The microbial agent, $T$. harzianum exhibited comparatively high antagonistic activity showing highest suppression of FoL in vitro. In hydroponic tanks, $T$. harzianum applied as root application, showed lowest root infection (15.39\%), leaf infection (18.09\%) and overall lower disease incidence (17.29\%) with highest crop growth attributes and yield. This was followed by treatment with consortia of $T$. harzianum and $B$. thuringiensis. The highest root infection $(85.08 \%)$, leaf infection $(70.02 \%)$, rot incidence $(80.97 \%)$ and lowest yield ( $30.00 \mathrm{~g} / \mathrm{plant})$ have been recorded in untreated lettuce plants in control tanks.
\end{abstract}

Keywords: Antagonists, Fusarium oxysporum f. sp. lactucae, hydroponic, lettuce

In conventional agriculture, crops are grown in open soil with or without irrigation, application of concentrated fertilizers and agrochemicals which possess numbers of notable negative impacts. The major downside of conventional crop cultivation includes - large patch of land requirement, inefficient and high use of fresh water, pest and disease pressure, nutrients and toxic pesticides runoff, soil degradation accompanied by erosion and other associated detrimental impacts on the environment (Killebrew and Wolff, 2014). Hydroponics, on the other hand, is growing plants on mineral nutrient solutions without soil is becoming a popular technology for commercial food production. Unlike conventional agriculture, hydroponic agriculture system of food crop production has a better control of pest and disease factors which reduces the requirement of plant protection chemicals and produces higher yield mostly free from chemical residues (Libia et al., 2012). This versatile crop cultivation system can range from rudimentary backyard setups to highly sophisticated commercial enterprises (Barbosa et al., 2015). In a controlled environment, it can support continuous production throughout the year. Other benefits of hydroponic culture are short production period, relatively better product quality and sanitation practices (Khater and Ali, 2015). Presently, hydroponic agriculture system has been successfully employed to

*Corresponding author: 2009parveenkhan@ gmail.com grow various commercial and specialty crops including strawberries, tomatoes, peppers, leafy vegetables, eggplants, cucumbers and much more.

Lettuce (Lactuca sativa) the second most important salad vegetable crop after tomato is currently cultivated in the hydroponic system either with or without artificial medium. This leafy vegetable performs best in the nutrient film technique or NFT (Tognoni et al., 2015). In conventional soil based system, lettuce crop is heavily affected by several diseases; among them, Pythium wilt and damping, Fusarium root rot, Rhizoctonia rot, lettuce drop (Sclerotinia minor) and bacterial soft rot (Pectobacterium carotovorum) are more common. Few of these diseases have also been detected in hydroponic culture systems, bringing a serious risk to hydroponic lettuce production (Jensen and Abad, 2009). The contamination of plant pathogens in hydroponic system can come from growing media, plant materials, insects, and through irrigation waters (Postma et al., 2008). The colonization is often triggered by steady temperatures and moisture regimes and the common fact that root colonizers can easily spread through recirculating water (Rosberg, 2014). In hydroponic systems, fungal development resulted from conidia bound to the root surface, which is the only source of carbon to support the growth of the fungus in the mineral nutrient solution 
(Chantal, 2006). Though these can be prevented by conventional chemical based methods but nonchemical measures should be preferred over chemical methods in hydroponics due to environmental, food safety and health concerns. The biological control involving antagonists and botanicals has been suggested to be ideally suited for the closed structure of soilless systems. Biocontrol agents can easily be added to nutrient solutions in a hydroponic system and be dispersed. The antagonistic ability of Trichoderma against different formae speciales of $F$. oxysporum has been well documented. The present study has been made to determine the suitability of bio-intensive approach by use of microbial antagonists for sustainable management of Fusarium rot disease in lettuce crop under the hydroponic system.

\section{MATERIALS AND METHODS}

The study was carried out in the laboratory and green shade net house of the Department of Plant Pathology, Assam Agricultural University, Jorhat, Assam, during 2014-2016.

\section{Hydroponic cultivation}

Artificial hydroponic culture tanks (HCT) were made using plastics tubs (30 inch x 18 inch) to grow lettuce plant variety "Linda" following 'Static Solution Technique'. Floating styrofoam boards were used as growing tray to place the seedlings in the upper side of the HCT tank. Disposable plastic glasses $(7.5 \mathrm{~cm}$ diam.) filled with sterilized coco peat were used as growing media and to keep the lettuce plants upright. Modifications were made in such way that 90 per cent of the disposal glass planted with lettuce plant remained inside the hydroponic solution. Artificial aqua tank air pumps were connected with the HCT tank for continuous aeration. As a source of micro and macro nutrients in required concentrations, artificial nutrient solution (Flora series, General Hydroponics, 32500 Fleurance, France) was used following manufacturer's guidelines. The nutrient rich HCT tank water was stirred at regular interval and the $\mathrm{pH}$ was adjusted to neutrality by adding dry $\mathrm{pH}$ down powder.

\section{Pathogen isolation}

Infected lettuce plants showing typical symptoms of Fusarium rot were collected from the horticultural orchard, AAU, Jorhat for isolation of the pathogen (Cabral et al., 2014). Potato dextrose agar (Himedia, Mumbai) supplemented with $20 \mathrm{mg}$ of tetracycline was used as a basal medium. For purification of the fungus, hyphal tip culture technique was employed. The isolated pure culture of the pathogen was maintained on PDA at $8^{\circ} \mathrm{C}$ to conduct subsequent experiments. The pathogenicity test of the isolated Fusarium culture was done as per the technique described by Zhao et al. (2014).

\section{Microbial antagonists}

Widely accepted three antagonists, viz., Trichoderma harzianum (MTCC 7477) Pseudomonas fluorescens
(MTCC 25036), Bacillus thuringiensis (MTCC 25035) were collected from the Biocontrol Laboratory of the Department of Plant Pathology, AAU, Jorhat, Assam. These were transferred to fresh medium and preserved at $4^{\circ} \mathrm{C}$ for evaluation study of their bioactive potential against Fusarium rot pathogen. The cultures of the fungal pathogen as well of all three antagonists T. harzianum, $P$. fluorescens and $B$. thuringiensis were maintained throughout the period of study in PDA, Nutrient Agar and King's B (Himedia, Mumbai) media respectively, by routine sub-culturing at regular intervals and stored at $4^{\circ} \mathrm{C}$.

\section{Evaluation of compatibility among different bioagents and development of microbial consortia}

Compatibility among the microbial bioagents was tested in vitro adopting dual culture assay plate technique with minor modification (Rahman et al., 2009) using PDA as basal media. The treatment combinations were: Growth of $T$. harzianum alone; $B$. thuringiensis alone; $P$. fluorescens alone; T. harzianum + B. thuringiensis; $T$. harzianum $+P$. fluorescens; $B$. thuringiensis $+P$. fluorescens; and T. harzianum $+B$. thuringiensis $+P$. fluorescens. The radial growths of each bioagent individually and in combinations were recorded upto 120 hrs of incubation.

\section{In vitro evaluation of antagonistic effect of different microbial bioagents against FoL}

The inhibitory effect of different antagonists and their combinations were tested in vitro against FoL adopting plate assay technique (Rahman et al., 2009) in pathogen favourable PDA medium. Agar plug of $5 \mathrm{~mm}$ diameter was prepared from $48 \mathrm{hr}$ old culture plates of Fusarium and T. harzianum and placed near the periphery of freshly prepared PDA plates. Similarly, agar plugs containing $48 \mathrm{hr}$ old culture of $P$. fluorescens and $B$. thuringiensis were scooped out from plate cultures and placed near the periphery of respective plates with the growth of $F$. oxysporum. The plates were then incubated at $28 \pm 1^{\circ} \mathrm{C}$ for $72 \mathrm{hrs}$. Fungal growths as colony diameter were measured and percentage inhibition was calculated following standard methods.

\section{Preparation of microbe-based bioformulation}

For the preparation of microbe-based bioformulation, the fungal and bacterial antagonists were at first multiplied individually in shake flasks using PD broth and nutrient broth respectively as a growth medium. The flasks containing $200 \mathrm{ml}$ of respective medium were inoculated with $48 \mathrm{hrs}$ old growth of $T$. harzianum. The inoculum was prepared by pouring sterile water into slant culture of the fungus and subsequently shaking gently to lodge the vegetative parts into the suspension. A loop of the inoculum suspension $\left(10^{8} \mathrm{cfu} / \mathrm{ml}\right)$ was transferred to flasks containing PD broth. Similarly, the bacterial antagonist $B$. thuringiensis and $P$. fluorescens were multiplied in individual flasks. Inoculated flasks were incubated at $28 \pm 1^{\circ} \mathrm{C}$ with orbital shaking at $150 \mathrm{rpm}$ for 


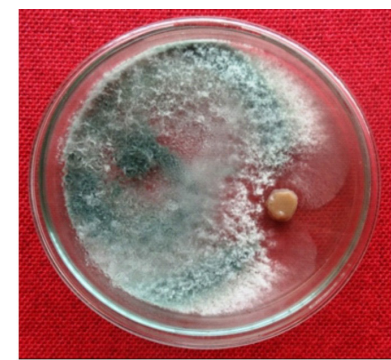

T. viride + P. fluorescens (PDA)

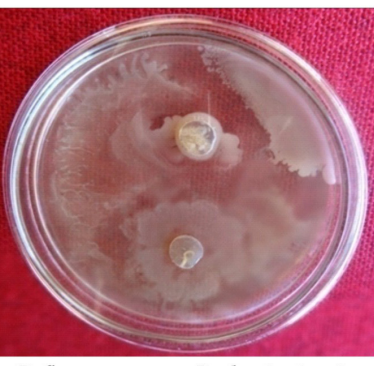

P. fluorescens + B. thuringiensis (PDA)

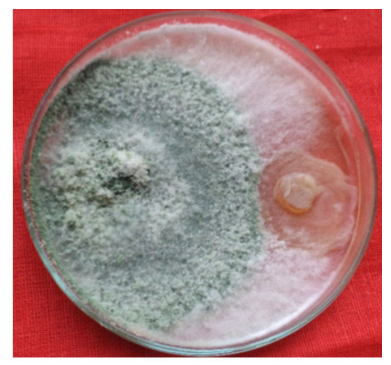

T. viride $+B$. thuringiensis (PDA)

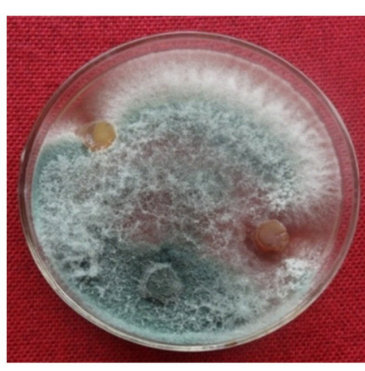

T. viride + P. fluorescens + B. thuringiensis (PDA)
Fig. 1. Compatibility reaction among different bioagents in PDA as basal media

72 and 48 hrs for fungal and bacterial antagonists respectively. The consortia formulation was prepared by mixing individual broth culture of $T$. harzianum, $B$. thuringiensis and $P$. fluorescens at a ratio of 1:1:1 after adjusting cell population to $10^{8} \mathrm{cfu} / \mathrm{ml}$ for each of the bioagents.

\section{In vivo evaluation of microbe-based bioformulation treatments}

The in vivo evaluation of antagonists based bioformulation was conducted in artificially infested hydroponic culture tanks under the net house. The inoculum of $F o L$ was prepared by culturing in PD broth in shake culture at $150 \mathrm{rpm}$, for 10 days at $28 \pm 2^{\circ} \mathrm{C}$ (Singh et al., 2013). The microconidia of the fungus were harvested by filtering through 4 layers of muslin cloth, centrifuged at $6000 \mathrm{~g}$ for $10 \mathrm{~min}$, adjusted to a spore population of $2 \times 10^{6} \mathrm{cfu} / \mathrm{ml}$ and was used to infest all the hydroponic tanks before planting. The antagonist based formulations were added to the nutrient solution before transplanting of lettuce seedling and again applied as spray after transplanting. After transplanting lettuce seedlings, the tanks were kept in the net house to protect from direct exposure to sunlight. The observations recorded during experimentation were - Disease incidence in roots and leaves (\%); dry weight of the roots (g); dry weight of the shoots $(\mathrm{g})$; height of the plant $(\mathrm{cm})$; yield/plant (g).

\section{RESULTS AND DISCUSSION}

\section{Compatibility among the bioagents}

In vitro study revealed that there was compatibility among the three bioagents viz., T. harzianum, P. fluorescens and B. thuringiensis (Fig. 1). All the three bioagents showing
Table 1. Results of compatibility test conducted with different bioagents

\begin{tabular}{lccc}
\hline Bioagents & T. viride & P.fluorescens & B. thuringiensis \\
\hline T. viride & $+\mathrm{ve}$ & $+\mathrm{ve}$ & $+\mathrm{ve}$ \\
P. fluorescens & $+\mathrm{ve}$ & $+\mathrm{ve}$ & $+\mathrm{ve}$ \\
B. thuringiensis & $+\mathrm{ve}$ & $+\mathrm{ve}$ & $+\mathrm{ve}$ \\
\hline
\end{tabular}

+ve - Positive (Compatible)

compatibility was selected for downstream experimentation (Table 1). Sumana and Devaki (2012) reported positive compatibility amongst antagonists like T. harzianum, B. subtilis and $P$. fluorescens in dual cultures. Similar compatible observations amongst bioagents like $P$. fluorescens, T. harzianum, and $B$. bassiana was made by Bora et al. (2013).

\section{Antagonistic effect of the bioagents against FoL}

The three compatible bioagents, viz., T. harzianum, B. thuringiensis, and $P$. fluorescens were tested against FoL singly and in consortia. Highest radial growth inhibition of FoL was recorded in case of T. harzianum (68.56\%) followed by consortia of $T$. harzianum and $B$. thuringiensis $(60.90 \%)$. This was followed by $B$. thuringiensis where 55.15 per cent growth inhibition recorded (Table 2).

Dagostin et al. (2011) reported that the bioagent Trichoderma has ability to produce a series of antibiotics and fungal cell wall degrading enzymes. These enzymes play important role in mycoparasitism and mycelia lysis of the target haustoria and hyphae. Ayer and Adam (1981) showed that T. harzianum could produce diffusible substances toxic to the pathogens and effectively act as ectoparasite by overcrowding the target organisms. Lee and Wu (1984) mentioned that T. harzianum could produce antibiotics and inhibit the mycelial growth of $S$. sclerotiorum completely and induce swelling and plasmolysis of target pathogen cells. Trichoderma sp. is known to produce different kinds of enzymes such as cell wall degrading enzyme, biotic and abiotic stress tolerance, mycoparasitism, antagonistic activity against different plant pathogens (Sharma et al., 2014). B. thuringiensis is a naturally abundant Gram-positive bacterium and a well-known, effective bio-insecticide. They have the ability to produce antimicrobials such as bacteriocins, which are actually inhibitory peptides or proteins against different pathogens (Mobolaji, 2009). Bacillus spp. acts as potential biocontrol agents of plant pathogenic fungi such as F. oxysporum, F. sambucinum, and F. graminearum (Baysal et al., 2013). Barruzi et al. (2011) reported a number of antifungal compounds, including polypeptides that interact with the fungal membrane, are produced by Bacillus species. $B$. thuringiensis can secrete chitinases and chitin-binding proteins; together these proteins control fungi by binding to cell wall chitin and disrupting the cell polarity, leading to fungal growth inhibition. The suppressive effect of $T$. harzianum and $B$. thuringiensis shown against $F o L$ in our study might be due to production of similar type of antimicrobials and toxins. 
Table 2. Suppressive effect of different antagonists and their consortia against radial growth of F. oxysporum f. sp. Lactucae

\begin{tabular}{lcr}
\hline Bioagents & Radial growth $(\mathrm{mm})$ & Inhibition(\%) \\
\hline F. oxysporum f. sp. lactucae (FoL) & 90.00 & $0.00(0.57)$ \\
T. harzianum + FoL & 12.25 & $68.56(55.86)^{*}$ \\
P. fluorescens + FoL & 40.00 & $46.91(43.22)$ \\
B. thuringiensis + FoL & 22.45 & $55.15(47.93)$ \\
T. harzianum + P. fluorescens + FoL & 57.0 & $37.23(37.58)$ \\
T. harzianum + B. thuringiensis + FoL & 21.25 & $60.90(51.30)$ \\
P. fluorescens + B. thuringiensis + FoL & 74.75 & $23.77(29.13)$ \\
T. harzianum + P. fluorescens + B. thuringiensis $+F o L$ & 49.50 & $42.09(40.40)$ \\
\hline S.Ed $( \pm)$ & & 1.77 \\
CD 0.05 & 3.02
\end{tabular}

*Data in the parenthesis are angular transformed values

Table 3. Effect of different microbe based bioformulations on incidence of root and leaf infections caused by $F$. oxysporum $\mathrm{f}$. sp. lactucae in hydroponically grown lettuce plants

\begin{tabular}{|c|c|c|c|c|}
\hline Treatments & $\begin{array}{l}\text { Root infection } \\
(\%)\end{array}$ & $\begin{array}{l}\text { Reduction of root } \\
\text { infection (\%) }\end{array}$ & $\begin{array}{l}\text { Leaf infection } \\
\qquad(\%)\end{array}$ & $\begin{array}{c}\text { Reduction of } \\
\text { Leaf infection (\%) }\end{array}$ \\
\hline $\mathrm{T}_{0}=$ Control & $85.08(67.21)^{\star}$ & 00 & $70.02(56.79)^{*}$ & 00 \\
\hline $\mathrm{T}_{1}=\mathrm{T}$. harzianum & $15.39(23.09)$ & 81.91 & $18.09(25.10)$ & 74.16 \\
\hline $\mathrm{T}_{2}=\mathrm{T}$. harzianum $+B$. thuringiensis & $22.73(27.83)$ & 73.28 & $23.64(29.06)$ & 66.23 \\
\hline $\mathrm{T}_{3}=B$. thuringiensis & $54.50(47.58)$ & 35.94 & $45.23(42.25)$ & 33.04 \\
\hline $\mathrm{T}_{4}=P$. fluorescens & $66.74(54.76)$ & 21.55 & $55.50(48.16)$ & 20.73 \\
\hline $\mathrm{T}_{5}=T$. harzianum $+P$. fluorescens $+B$. thuringiensis & $29.58(32.90)$ & 65.23 & $29.45(32.83)$ & 57.94 \\
\hline $\mathrm{T}_{6}=T$. harzianum + P. fluorescens & $42.18(40.46)$ & 50.42 & $36.15(36.93)$ & 48.37 \\
\hline $\mathrm{T}_{7}=P$. fluorescens $+B$. thuringiensis & $75.29(60.13)$ & 11.50 & $60.70(50.77)$ & 13.31 \\
\hline S. Ed $( \pm)$ & 2.49 & & 2.34 & \\
\hline $\mathrm{CD}_{0.05}$ & 4.25 & & 4.00 & \\
\hline
\end{tabular}

*Data in the parenthesis are angular transformed values

Antagonist mixtures have been thoroughly investigated in soil systems, especially against pathogenic taxa such as Fusarium spp. and Pythium spp., where enhanced disease control of root infecting pathogens has been attained with multi-strain mixtures (Lemanceau et al., 1992). In the present study combination of $T$. harzianum and $B$. thuringiensis significantly reduced the mycelial growth of FoL. A similar observation was reported by Kamala and Devi (2012).

\section{Effect of microbe-based bioformulations on lettuce disease infection in hydroponic tank}

Significant reduction of root and leaf infection of lettuce crop has been observed when antagonist based bioformulations were applied into the hydroponic tank. Lowest root infection (15.39\%), as well as leaf infection (18.09\%), was recorded in the tanks treated with $T$. harzianum $\left(1 \times 10^{8} \mathrm{cfu} / \mathrm{ml}\right)$ alone as root application along with the nutrient solution. This treatment was followed by consortia of $T$. harzianum and $B$. thuringiensis where 22.73 per cent and 23.64 per cent root and leaf infection was recorded respectively (Table 3 ). Reduction in root infection (81.91\%) and leaf infection $(74.16 \%)$ was recorded highest in $T$. harzianum treated tank followed by $T$. harzianum and $B$. thuringiensis combine treatment where 73.28 per cent and 66.23 per cent reduction in root and leaf infection was recorded respectively. Highest root $(85.08 \%)$ and leaf infection $(70.02 \%)$ has been recorded in the untreated control tank.

Application of the bioagents significantly reduced the root and leaf disease incidence in lettuce. The significant decrease of root and leaf infection of lettuce was recorded in two best treatments, i.e., T. harzianum, as well as $T$. harzianum and $B$. thuringiensis based bioformulations applied as combinations of root and foliar treatments might have occurred due to direct effects of the bioagents on the suppression of the pathogen population. Trichoderma species have the ability to control many soil-borne plant diseases caused by fungi (Elad et al., 1980). Successful reductions of Fusarium rot in many crops with the application of different species of Trichoderma have been recorded earlier (Ramezani, 2009).

\section{Effect of microbe-based bioformulation on disease incidence and yield attributing characters}

All the three microbial bioagents $T$. harzianum, $B$. thuringiensis and $P$. fluorescens significantly improved 
Table 4. Effect of different antagonist based bioformulations on growth parameters of hydroponically grown lettuce plant

\begin{tabular}{|c|c|c|c|c|c|c|c|c|}
\hline \multirow[t]{2}{*}{ Treatments } & \multicolumn{8}{|c|}{ Growth characteristics } \\
\hline & $\begin{array}{l}\text { Shoot } \\
\text { length } \\
(\mathrm{cm})\end{array}$ & $\begin{array}{l}\text { Root } \\
\text { length } \\
(\mathrm{cm})\end{array}$ & $\begin{array}{l}\text { No of } \\
\text { leaves }\end{array}$ & $\begin{array}{l}\text { Shoot dry } \\
\text { weight } \\
\text { (g) }\end{array}$ & $\begin{array}{l}\text { Root dry } \\
\text { weight } \\
\text { (g) }\end{array}$ & $\begin{array}{l}\text { No of } \\
\text { roots }\end{array}$ & $\begin{array}{l}\text { Root fresh } \\
\text { weight } \\
\text { (g) }\end{array}$ & $\begin{array}{c}\text { Yield } \\
\text { (g/plant) }\end{array}$ \\
\hline $\mathrm{T}_{0}=$ Control & 6.87 & 2.62 & 5.00 & 0.48 & 0.25 & 11.00 & 2.07 & 30 \\
\hline $\mathrm{T}_{1}=\mathrm{T}$. harzianum & 35.00 & 28.25 & 23.00 & 18.04 & 5.95 & 56.00 & 28.12 & 251.25 \\
\hline $\mathrm{T}_{2}=T$. harzianum $+B$. thuringiensis & 29.25 & 24.50 & 19.00 & 15.00 & 4.30 & 53.00 & 24.37 & 221.75 \\
\hline $\mathrm{T}_{3}=B$. thuringiensis & 16.00 & 12.25 & 10.00 & 6.35 & 0.89 & 32.00 & 12.15 & 80.25 \\
\hline $\mathrm{T}_{4}=P$. fluorescens & 13.67 & 8.50 & 8.00 & 2.77 & 0.54 & 26.00 & 7.82 & 63.50 \\
\hline $\mathrm{T}_{5}=T$. harzianum $+P$. fluorescens $+B$. thuringiensis & 24.00 & 20.50 & 15.00 & 12.05 & 2.82 & 49.00 & 20.67 & 187.75 \\
\hline $\mathrm{T}_{6}=T$. harzianum $+P$. fluorescens & 20.25 & 16.50 & 12.00 & 9.41 & 1.40 & 40.00 & 16.80 & 140.00 \\
\hline $\mathrm{T}_{7}=P$. fluorescens $+B$. thuringiensis & 9.75 & 6.875 & 6.00 & 0.90 & 0.36 & 19.00 & 4.97 & 44.50 \\
\hline S. Ed $( \pm)$ & 1.32 & 1.13 & 1.09 & 0.54 & 0.29 & 2.04 & 0.91 & 6.57 \\
\hline $\mathrm{CD}_{0.05}$ & 2.25 & 1.93 & 1.86 & 0.92 & 0.49 & 3.48 & 1.55 & 11.20 \\
\hline
\end{tabular}

the growth parameters as compared to the untreated control. The highest growth attribute in terms of shoot length $(35.00 \mathrm{~cm})$, root length $(28.25 \mathrm{~cm})$, no. of leaves (23.00), shoot dry weight (18.04 g/plant), root dry weight (5.95 g/plant), root fresh weight ( $28.12 \mathrm{~g} /$ plant) and total biomass (251.25 g/plant) of lettuce plants was recorded with application of bioformulation of T. harzianum alone. This was followed by application of consortia formulation of T. harzianum and B. thuringiensis (Table 4).

Similarly, Trichoderma spp. have been reported to enhance plant height, leaf number, tiller number, root length and root fresh weight of rice (Doni et al., 2014). The yield of lettuce treated with consortia of different bioagents followed similar trend as recorded for root and leaf infection (Table 3). Highest yield ( $251.25 \mathrm{~g} /$ plant) with lowest overall disease incidence (17.29\%) was recorded in the tanks treated with bioformulation containing $T$. harzianum alone followed by treatment with consortia of T. harzianum and B. thuringiensis where $26.13 \%$ rot incidence and $221.75 \mathrm{~g} /$ plant healthy harvest has been observed. The highest fungal rot incidence $(80.97 \%)$ and lowest yield (30.00 g/plant) of lettuce were recorded in the control treatment where no bioformulation was applied. The increase in yield and decrease in disease incidence might be due to suppression of the pathogen due to the application of bioagents. This finding is in agreement with Bustamante et al. (1989). In our study, the plant height and yield increased in T. harzianum treated plants. Similar results of increased plant growth due to the application of Trichoderma gamsii in cereals and legume crops have been reported earlier (Rinu et al., 2013). The increase of plant growth might be associated with secretion of auxins, gibberellins and cytokinins. Moreover, Alippi and Monaco (1994) reported that $B$. subtilis can secrete several antifungal metabolites such as subtilin, bacitracin, bacillin and bacillomycin which have inhibitory effects on fungal pathogens. Yang et al. (2014) reported that $B$. subtilis exerted a heat stable antibiotic interfering with spore germination, or early germ tube development of stone fruit brown rot pathogen. The present finding suggests that suppression FoL by Bacillus sp. could be due to similar type of mechanisms. Manikandan and Raguchander (2015) reported that liquid formulation of strain Pf1 has six month shelf life and enhanced disease resistance in tomato plants against Fusarium wilt disease. The present finding suggests that suppression of FoL could be due to similar type of resistance. Van Peer and Schippers (1989) reported that bacterization of hydroponic nutrient solution with plant-growth-promoting Pseudomonas strains increases root and shoot mass of tomato, cucumber, lettuce, and potato most likely by suppressing deleterious rhizosphere microflora.

The application of microbe-based bioformulation of $T$. harzianum or consortia formulation of $T$. harzianum and $B$. thuringiensis as root treatment and foliar spray application can be effective biocontrol option for management of fungal rot of hydroponically grown lettuce plant. Increasing population and declination of arable land due to poor land management, people may adopt new technologies like the soil-less culture of crop production with bio-intensive management practices.

\section{ACKNOWLEDGEMENTS}

The authors are highly thankful to the Department of Plant Pathology and DBT-AAU Centre, Assam Agricultural University, Jorhat, Assam for providing facilities and financial assistance to carry out the studies.

\section{REFERENCES}

Alippi A and Monaco C (1994). Antagonismo in vitro de especies de Bacillus Contra Sclerotium rolfsii, Fusarium solani. Revista de la Facultad de Agronomia La Plata 70: 91-95.

Ayer WA and Adam PB (1981). Mycoparasitism and its application to biological control of plant diseases. In: Biological Control in Crop Protection. Papavizas GC (eds.). BARC Symposium: 91-103.

Barbosa GL, Kublik N, Proctor A, Reichelm L, Weissinger E, Wohlleb GM and Halden RU (2015). Comparison of land, water, and energy requirements of lettuce grown using 
hydroponic vs. Conventional agricultural methods. Int. J. Environ. Res. Public Health 12: 6879-6891.

Barruzi F, Quientieri L, Morea M and Caputp L (2011). Antimicrobial compounds produced by Bacillus spp. and applications in food. Science against microbial pathogens: communicating current research and technological advances. 1102-1111.

Baysal Ö, Karaaslan C, Siragusa M, Alessandro R, Carimi F, Pasquale F and Teixeira da Silva JA (2013). Molecular markers reflect differentiation of Fusarium oxysporum forma speciales on tomato and forma on eggplant. Biochem. Sys. Ecol. 47: 139-147.

Bora LC, Deuri D and Kataky L (2013). RAPD analysis of ginger germplasms of North East India and assessment of their resistance against bacterial wilt disease caused by Ralstonia solanacearum. In: World Biodiversity Congress, Global Scientific Research Foundation, Chiang Mai and Rajabhat University, Chiang Mai, Thailand.

Bustamante GP, Ciampi-Panno L and Guaiquil GV (1989). Inhibition in vitro of Pseudomonas solanacearum E.F. Smith using antagonistic strains of Pseudomonas fluorescens. Revista de. Microbiologia (Abstr.).

Cabral CS, Brunelli KR, Costa H, Fonseca ME, Boiteux LS and Reis A (2014). Identification of Fusarium oxysporum f. sp. lactucae race 1 as the causal agent of lettuce wilt in Brazil. Trop. Plant Pathol. 39: 197-202.

Chantal O (2006). Colonization of tomato roots by pathogenic and non pathogenic Fusarium oxysporium strains inoculated together and separately into the soil. Appl. Environ. Microbiol. 72: 1523-1531.

Doni F, Isahak H and Yusoff, WMW (2014). Physiological and growth response of rice plants (Oryza sativa L.) to Trichoderma spp. inoculants. AMB Express 4: 45.

Dagostin S, Scharer HJ, Pertot I and Tamm L (2011). Are there alternatives to copper for controlling grapevine downy mildew in organic viticulture. Crop Prot. 30: 776-788.

Elad Y, Chet I and Katan J (1980). Trichoderma harzianum: a biocontrol effective against Sclerotium rolfsii and Rhizoctonia solani. Phytopathology 70: 119-121.

Jensen CE and Abad GZ (2009). Fusarium solani species complex newly identified to cause root rot in hydroponically grown lettuce and cilantro in Puerto Rico. Plant Pathol. 58: 801 .

Kamala T and Devi IS (2012). Biocontrol properties of indigenous Trichoderma isolates from North-east India against Fusarium oxysporum and Rhizoctonia solani. Afr. J. Biotechnol. 11: 8491-8499.

Khater EG and Ali SA (2015). Effect of flow rate and length of gully on lettuce plants in aquaponic and hydroponic systems. J. Aquac. Res. Development 6: 318.

Killebrew K and Wolff H (2014). Environmental Impacts of Agricultural Technologies. Evans School of Public Affairs. University of Washington. http://econ.washington.edu/files/ 2014/06/2010-Environmental-Impacts-of-Ag Technologies.

Lee $Y$ and Wu W (1984). The antagonisms of Trichoderma sp. and Gliocladium virens against Sclerotinia sclerotiorum. Plant Protection Bulletin (Taiwan. ROC) 26: 293-304.

Lemanceau P, Bakker PAHM, De Kogel WJ, Alabouvette C and Schippers B (1992). Effect of pseudobactin 358 production by Pseudomonas putida WCS358 on suppression of
Fusarium wilt of carnations by non-pathogenic Fusarium oxysporum Fo47. Appl. Environ. Microb. 59: 74-82.

Libia I, Trejo-Téllez and Fernando C Gómez-Merino (2012). Nutrient Solutions for Hydroponic Systems In: Hydroponics - A Standard Methodology for Plant Biological Researches. Colegio de Postgraduados, Montecillo, Texcoco, State of Mexico.

Manikandan R and Raguchander T (2015). Pseudomonas fluorescens (Pf1) mediated chitinolytic activity in tomato plants against Fusarium oxysporum f. sp. lycopersici. Afr. J. Microbiol. Res. 9: 1331-1337.

Mobolaji AO (2009). Antimicrobial activity of bioactive compound(s) produced by Bacillus species. Final Report For Microbial Diversity Course.

Postma J, Van OS, EA and Bonants PJM (2008). Pathogen detection and management strategies in soilless plant growing systems. In: Raviv M and Lieth JH (eds) Soilless culture - theory and practice. USA: Elsevier BV 425-458.

Rahman MA, Begum MF and Alam MF (2009). Screening of Trichoderma isolates as a biological control agent against Ceratocystis paradoxa causing pineapple disease of sugarcane. Mycobiology 37: 277-288.

Ramezani H (2009).Efficacy of some fungal and bacterial bioagents against Fusarium oxysporum f.sp. ciceri on chickpea. Plant Prot. J. 1: 108-113.

Rinu K, Sati P and Pandey A (2013). Trichoderma gamsii (NFCCI 2177): a newly isolated endophytic, psychrotolerant, plant growth promoting and antagonistic fungal strain. J. Basic Microbiol. 54: 408-417.

Rosberg AK (2014). Dynamics of root microorganisms in closed hydroponic cropping systems. Doctoral thesis Swedish University of agricultural Sciences. 1-62.

Sharma P, Sharma M, Raja M and Shanmugam V (2014). Status of Trichoderma research in India : A review. Indian Phytopath. 67: 1-19.

Singh SP, Singh HB and Singh DK (2013). Trichoderma harzianum and Pseudomonas sp. mediated management of Sclerotium rolfsii rot in tomato (Lycopersicon esculentum Mill.). The Bioscan 8: 801-804.

Sumana K and Devaki NS (2012). In vitro evaluations of some bioagents against tobacco wilt pathogen. J. Biopest. 5: 1822.

Tognoni F and Pardossi A (2015). Chapter 15: Soil-less Culture for Greenhouse Crops in the Mediterranean Countries. Methyl Bromide Alternatives for North African and Southern European Countries. United Nations Publication. http://www.unep.fr/ozonaction/information/mmcfiles/3204e.pdf. Accessed 30 January 2015.

Van Peer R and Schippers B (1989). Plant growth responses to bacterization with selected Pseudomonas spp. strains and rhizosphere microbial development in hydroponic cultures. Can. J. Microbiol. 35: 456-463.

Yang SC, Lin HC, Sung TC and Fang YJ (2014). Antibacterial activities of bacteriocins: application in foods and pharmaceuticals. Front. Microbial. 5: 241.

Zhao B, Yan J, Zhang S, Liu X and Gao Z (2014). Phylogeny and pathogenicity of Fusarium spp. isolated from greenhouse melon soil in Liaoning Province. Saudi J. Biol. Sci. 21: 374-379. 